Genet, N., Kroneman, M., Boerma, W.G.W. Explaining governmental involvement in home care across Europe: an international comparative study. Health Policy: 2013, 110(1), 84-93

nivel

\begin{tabular}{|l|l|}
$\begin{array}{l}\text { Postprint } \\
\text { Version }\end{array}$ & 1.0 \\
\hline Journal website & $\underline{\text { http://www.healthpolicyirnl.com/article/S0168-8510(13)00019-5/abstract }}$ \\
\hline Pubmed link & $\underline{\text { http://www.ncbi.nlm.nih.gov/pubmed/23399041 }}$ \\
\hline DOI & 10.1016/j.healthpol.2013.01.009 \\
\hline
\end{tabular}

This is a NIVEL certified Post Print, more info at http://www.nivel.eu

\title{
Explaining governmental involvement in home care across Europe: An international comparative study
}

\author{
NADiNE GENET ${ }^{1,}$, MADELON KRONEMAN ${ }^{1,}$, WIENKE G.W. BOERMA ${ }^{1,}$ \\ NIVEL (Netherlands Institute for Health Services Research), PO Box 1568, 3500 BN Utrecht, \\ The Netherlands
}

\begin{abstract}
The involvement of governments in the home care sector strongly varies across Europe. This study aims to explain the differences through the conditions for the involvement of informal care and governments in society; wealth and the demographic structure. As this study could combine qualitative data and quantitative data analyses, it could consider larger patterns than previous studies which were often based on ideographic historical accounts. Extensive data were gathered in 30 European countries, between 2008 and 2010. In each country, policy documents were analysed and experts were interviewed. International variation in regulation and governmental funding of personal care and domestic aid are associated with differences in prevailing values on family care, tax burden and wealth in a country. Hence, this study provides evidence for the obstacles - i.e. country differences - for transferring home care policies between countries. However, longitudinal research is needed to establish whether this is indeed the causal relationship we expect.
\end{abstract}

\section{INTRODUCTION}

Home care, ranging from technical nursing to domestic aid, is increasingly drawing the attention in debates about sustainable health care systems in the future [1], [2], [3] and [4]. Decision makers see home care as a potentially cost effective way of maintaining people's independence and home care is also the mode of care preferred by recipients [1]. Despite this growing interest, expenditure and efficiency in the home care sector are critically considered [1]. Between 2003 and 2009 expenditures on home health care have been rising in many EU countries [5] but more importantly it is expected to grow with the ageing of the populations [1].

Marketisation, context-related regulation, leaving care up to families or rather the governments taking the provision into their own hands are thought to affect the 
Genet, N., Kroneman, M., Boerma, W.G.W. Explaining governmental involvement in home care across Europe: an international comparative study. Health Policy: 2013, 110(1), 84-93

efficiency and effectiveness of home care. In their pursuit of more efficient and effective home care, policy makers could be inspired by the ways in which home care is governed in other countries. This raises the question whether such policies can indeed be transferred to other countries. A first step would be gaining insight into why policies differ, one of the purposes of international comparative studies into the role of governments [6]. The policy convergence theory stresses the importance of economic development in explaining differences in policies, while other theories point to the other national features that thwart the success of policy transfer [2]. International comparative studies on care services have referred to systematic and enduring differences between countries due to cultural, economic and labour market differences as well as institutional inertia [2], [7], [8], [9] and [10]. However, most of these studies provided a small number of ideographic historical accounts of longterm care and, hence, the association between governmental role and country differences was difficult to proof.

Governmental involvement in home care can take several forms. For instance, a first indication of governmental involvement is provided in the form of policy visions on home care, laid down by governments. Involvement in funding may consist of actual financing of home care. Regulation of home care may involve the control of and setting rules for quality of care, price setting and the formulation of eligibility criteria. Involvement in provision may take the form of actually providing home care by governmental agencies.

\subsection{Research question}

Our question is "to what extent can differences among European countries regarding governmental involvement in the home care sector be explained by differences in culture, economy, labour market participation of women or political leaders of a country?'

In our study, home care refers to formal domestic aid (e.g. housekeeping), personal care (e.g. assistance with dressing, feeding and washing) and home nursing (rehabilitative, supportive and technical) provided to adults living at home. As in most countries home care governance is politically highly decentralised, especially regarding domestic aid and personal care [7], both national and local governments have been considered. In line with numerous previous comparative studies in the area of long-term care [2], [7], [9] and [10], three types of governmental involvement in the home care sector are distinguished: funding, regulation and provision of services.

\subsection{Explaining differences in governmental involvement}

This paper aims to explain international differences in care policies. Variation in family values are thought to contribute to cross-country differences in governmental involvement with care [2], [8], [9] and [11]. For example, involvement in the home care sector may be a lower priority for the government where the prevailing family value holds that women should give up work to care for their dependent elderly parents [8]. In the gender division in responsibilities for care and the relations and responsibilities between generations, four models can be distinguished: the housewife, female part-time carer, dual breadwinner/institutional care and dual breadwinner/female carer model [2]. These are also thought to explain differences in governmental involvement in care. 
Genet, N., Kroneman, M., Boerma, W.G.W. Explaining governmental involvement in home care across Europe: an international comparative study. Health Policy: 2013, 110(1), 84-93

The role of governments with home care may also result from the political set up of governments in the past [12] and welfare values, i.e. cultural values about the role of public institutions in caring [8]. Left-wing parties, such as Social-democrats, generally put more emphasis on the role of governments in society and, in particular, on income redistribution. Public expenditures on health care and the population coverage of public medical care programmes appeared to be higher in countries with a more prominent representation of Social-democrats in cabinets during a series of years compared to countries in which Christian-democratic and - especially - liberal parties were dominant [13].

Economic and demographic conditions may influence governmental involvement [9] and [14], such as the degree of privatisation in health care delivery. In better economic conditions governments receive more income, and consequently more resources may be available. Finally, with the ageing population, demand for home care is likely to increase and, as representatives of society, governments may be urged to tale up a more active role in the home care sector.

As possible correlates of governmental involvement in home care, this study specifically explores economic and demographic conditions; tax burden; the seats of Social-democratic parties in the cabinets over the past decade; and the cultural values related to the role of family and the state for care and female labour market participation.

The above considerations result in the following hypotheses:

1. .In countries where the conditions for the involvement of informal care are better (measured through lower labour market participation of women and a more strong believe in caring for own family members), the involvement of governments in home care is lower.

2. .In countries where the role of government in society is stronger (measured through higher tax burden, higher share of cabinet seats for Social-democrats over the years and a stronger belief in an active role of the government in care), governments are more involved in home care.

3. .In wealthier countries, governmental involvement in home care is stronger.

4. .In countries where the proportion of elderly people in the population is relatively large, governmental involvement in home care is stronger.

\section{METHODOLOGY}

\subsection{Data gathering}

The study included 31 countries, among which 26 EU countries (excluding Portugal), Croatia, Iceland, Norway and Switzerland. Between 2008 and 2010 data were gathered, through the EURHOMAP-project, on more than 100 structural indicators on home care. Although the OECD Health Database and the Eurostat database also include data on home care, these provide little data, data are often difficult to compare and do not provide information on the organisation of care (either due to the many differences in definition between countries or due to the lack of context to 
Genet, N., Kroneman, M., Boerma, W.G.W. Explaining governmental involvement in home care across Europe: an international comparative study. Health Policy: 2013, 110(1), 84-93

interpret the data). In contrast, the EURHOMAP database thus contains a mix of quantitative and qualitative data. Qualitative data refer to the organisation of financing, policies, mode of needs assessment and delivery, while quantitative data are available about funding and the recipients of home care. Information on 'real life' home care was gathered by means of four structured case narratives with related questionnaires. The indicators used in this study resulted from a systematic literature review [3] and consultations with a panel of researchers in the field of home care. Information has been collected from databases and documents in the countries (policy papers, legislation, scientific papers, reports and websites) and interviews with around 10 experts in each country (including decision makers at national and local level; managers or coordinators in home care organisations; and experts from insurance companies, assessment agencies and research.

\subsection{Operationalization}

As no ready-made measures were available for governmental involvement in home care, we compiled proxy indicators for involvement in funding, regulation and service provision respectively.

The extent of benefits funded by government, is a widely used indicator for characterising the role of the welfare state [8], [15] and [16]. In our study this is established through the number of publicly funded services (i.e. housekeeping, shopping, administration, meals-on-wheels, washing, dressing, eating, putting on aids, transfers in the home, changing stoma's, skin care and help with using medicine) weighted by whether they were available for all people (higher score) or only for people from a lower socio-economic class (lower score). This weighting refers to a second indicator that characterises the role of the welfare state, i.e. the level of universalism [12]. The indicator for level of involvement in regulation was constructed from context related regulation [17] on quality, price and eligibility. Setting regulation is seen as one of the three instruments with which the welfare state can influence the home care sector [2] and [17]. The government can also steer the home care sector by taking up operational roles, i.e. by providing care and assessing individual care needs [2]. Since strong involvement in a small safety net type of home care scheme is not comparable to strong involvement in a comprehensive system, the scale and breadth of publicly funded home care services provided by the government is taken into account. As involvement in regulation and provision almost exclusively concerns publicly funded services, this was weighted by the

governmental involvement in funding. 'Involvement in funding', 'involvement in regulation' and 'involvement in service provision' were each measured by taking the means of the scores of their two or three individual indicators. Governmental involvement scores ranged from zero ('none') to one ('strong'). As the study focus is primarily on national governments, involvement at the national level will get a stronger weight than involvement at regional or municipal level. Supplementary data 1 provides a detailed account of variable constructions.

The conditions for the involvement of informal care were operationalised as a combination of the dominant family value in a country and female labour market participation. The dominant family value in a country is operationalised by the proportion of respondents in the Special Eurobarometer of 2007 that agreed that 
Genet, N., Kroneman, M., Boerma, W.G.W. Explaining governmental involvement in home care across Europe: an international comparative study. Health Policy: 2013, 110(1), 84-93

"Care should be provided by close relatives of the dependent person, even if that means that they have to sacrifice their career to some extent" as measured [18]. Female labour participation consists of the percentage of the female population between age 15 and 64 that is in paid employment in full-time equivalents in 2007; assuming that a lower share relates to a higher availability of informal carers [19]. The final indicator for the conditions for the involvement of informal care combine the averages of the relative country scores on each indicator (relative means that these are compared to the average score across countries). This was done only after making the indicators of informal care unidirectional, i.e. reversing the score on labour market participation of women.

For most countries it is unknown what family model prevails. Hence, we had to assign these countries to models using several indicators - selected based on Bureau et al.'s description of these models [3]. Indicators were the opinion on family care in combination with female labour market participation. If less than $25 \%$ of the country's respondents agreed that children should take care of their dependent elderly parents even if it is at expense of their job and at least 55\% of women in the working age were employed we assumed there to be a dual breadwinner/institutional care model. If it was the other way around, we assumed the housewife model to prevail. When the country scored $25 \%$ and $55 \%$ respectively on these two indicators we assumed the dual breadwinner/female carer model was prevalent. Finally, we assigned countries where more than $30 \%$ of the working women worked part-time to the group of the female part-time carer. In case of opinion indicator above $25 \%$ is high and in case of the labour market participation of women this is said to be high if over $55 \%$.

The role of the government in society in general consists of three different aspects. First, the average percentage of cabinet posts held by Social-democratic parties between 1992 and 2008 [20]. Second, we used the governmental revenues, such as current taxes and social contributions on income and wealth as a share of GDP in 2007 [21]. Third, the dominant welfare value was used, operationalised as the proportion of respondents in the 2007 Special Eurobarometer survey believing that the state should provide care for elderly dependent people [18]. The final indicator for government involvement in society was composed in the same way as the final indicator for the conditions for informal care.

Wealth was operationalised as the GDP per capita in Euro against current prices in 2009 [22]. The old-age dependency ratio was derived from Eurostat for 2010 [23]. Supplementary data 1 provides a description of the exact construction of the data and supplementary data 2 provides the descriptive statistics.

\subsection{Data analyses}

Taking the qualitative character of the information into account ranked data was used to identify correlations, rather than nominal values resulting from our calculation.

The strength of Spearman's ranking correlation is assessed following Davis [24]. As the number of observations was small, we limited to bivariate analyses. In the analyses governmental involvement was separately considered for domestic aid, personal care and home nursing respectively, as governmental regulations and programmes rarely cover all three [7]. The reason for this was that in many countries, 
Genet, N., Kroneman, M., Boerma, W.G.W. Explaining governmental involvement in home care across Europe: an international comparative study. Health Policy: 2013, 110(1), 84-93

the state is more involved with professional and medically oriented care, i.e. nursing care, than with help oriented tasks such as domestic aid [2] and [25].

\section{RESULTS}

\subsection{Descriptives}

Firstly, an overview will be provided of the different types of governmental involvement in the European countries. In most countries, national governments have formulated a policy vision about the role and content of home care, however, such visions usually were neither detailed nor homogenous. The lack of detail may result from the high level of political decentralisation in home care, especially as regards domestic aid and personal care. More detailed visions are found with local governments. Lack of homogeneity stems from the different origins of home health care, including nursing care (which normally is part of the health care system) and social home care, including domestic aid (which usually belongs to the social care system in a country). In over half the countries, home health and social home care are regulated by different ministries. Exceptions are the Scandinavian countries, France, England, Ireland, the Netherlands and some smaller countries. As a consequence, governmental regulations, programmes and visions rarely cover both social home care and home health care. Furthermore, policy papers and regulations often do not focus exclusively and even not mainly on home care. Most of them focus on long-term care in general, such as those in the Netherlands and in Germany, or on policies for the elderly, like those in France and Slovenia.

Most home care services considered in this study are, at least partially, funded from public resources, except in Bulgaria, Croatia and Romania (see Table 1). The population for which publicly funded services are available is most restricted for domestic aid and most universally for home nursing, with personal care somewhere in between (for the average scores see Supplementary data 2). Overall, governments are most strongly involved in the funding of home nursing and least in domestic aid. Governmental involvement in funding is relatively high in the Scandinavian countries and France, Germany, the Netherlands and Switzerland. Personal care services are most likely to be publicly funded, however, often it was only for a limited segment of the population.

\section{[TABLE 1]}

Countries also strongly differ in the level of regulation (see Table 1). Those with strongest governmental regulation are Germany and Norway, in contrast to Ireland, Poland and Bulgaria, where regulation is weakest. Home nursing care tends to be more regulated than domestic aid and personal care. Governmental regulation aiming to control the quality of care is poorly developed (see Table 1 ). In very few countries the concept of quality has been well defined. If quality criteria do exist at all, they are usually set at lower administrative level. Regulation on quality mainly concerns minimum organisational standards and quality inspections. Regulation on the quality of care which is completely privately financed is rarely found. Prices for domestic aid and personal care paid by recipients, governments and third parties together, are usually not set at national levels (see supplementary data 2). In several countries, local governments have the possibility to negotiate prices with providers, e.g. in the Scandinavian countries, the Slovak Republic and Switzerland. Even though price 
Genet, N., Kroneman, M., Boerma, W.G.W. Explaining governmental involvement in home care across Europe: an international comparative study. Health Policy: 2013, 110(1), 84-93

setting is often decentralised, central governments may set national guidelines for prices. For home nursing, governments have a stronger role in price setting than for the other types of home care. In most countries, access to publicly funded home care services is regulated by criteria of eligibility. Criteria are usually set in general terms nationally, and more often apply to home nursing than to other types of home care. Local governments, and sometimes even private providers, may then further elaborate nationally set eligibility criteria.

\subsection{Differences explained}

\section{Hypothesis 1}

. Stated that governmental involvement in home care is lower in countries where conditions for informal care are better. In Sweden, Denmark, Finland and Norway, the main family model is the dual breadwinner model (see Table 2). Therefore, in line with the hypothesis, the role of informal care givers is expected to be low. In these countries we find a strong governmental involvement in funding and the delivery of services (see Table 1). The dual earner - part-time carer model prevails in Austria, Belgium, England, France, Germany and the Netherlands. With the exception of England, these countries have a relatively high governmental involvement in home care funding and relatively low involvement in the provision of these services. In the countries where a housewife model or a dual breadwinner/female carer model prevails, it is more difficult to identify a pattern. The housewife model is prevalent in the Southern European countries, Hungary, Poland and Estonia. In the other Eastern European countries it is mainly a dual breadwinner/female carer model. The Southern countries all have in common that funding and regulation is much stronger controlled by government for home nursing than for the other types of home care.

\section{[TABLE 2]}

To see whether there is a significant association between these models and the level and type of governmental involvement, we looked at the individual indicators for the conditions for informal care. The dominant family value in a country is found to be associated with governmental involvement in funding and regulation over personal care and domestic aid (see Table 3). On average, the more people believe one should care for elderly parents if they need help, the less governments tend to be involved in funding and regulating these home care services. The dominant family value does not seem to play a role in governmental involvement in care provision. However, the involvement in home nursing and personal care provision is moderately positively associated with the labour market participation of women.

\section{Hypothesis 2}

. Stated that a stronger overall role of government in society was associated with stronger involvement in home care. In Sweden, Denmark and Cyprus the share of inhabitants that see an important role for the state in providing care was highest (see Table 2). This dominant welfare value was found to be moderately associated with funding of home nursing and personal care services, but not with involvement in other types of home care. Social-democratic parties have been resented most in 
Genet, N., Kroneman, M., Boerma, W.G.W. Explaining governmental involvement in home care across Europe: an international comparative study. Health Policy: 2013, 110(1), 84-93

cabinets in Sweden, England and Greece and least in Malta and Iceland (see Table 2). The position of Social-democratic parties in cabinets over the past decade is not associated with governmental involvement in home care. In contrast, a higher tax burden is substantially associated with more involvement in funding and regulating domestic aid and personal care. Tax burdens are highest in the Scandinavian countries, Belgium and the Netherlands, all three countries having a strong involvement in funding and regulation of home care.

\section{Hypothesis 3}

. Stated that governmental involvement in home care is stronger in wealthier countries. The wealth differs extremely between countries: the Gross Domestic Product in purchasing power per person for the wealthiest country (Luxembourg) was more than 16 times that of the poorest country (Bulgaria). In general, the wealth in Eastern European countries is lowest and followed by the Mediterranean countries. None of the $50 \%$ least wealthy countries has a dual breadwinner or dual earner - part-time carer model. Hence, these two explanatory variables do seem to be associated (Table 2). Governmental involvement in funding is very high in the four wealthiest countries, while in the four poorest countries involvement in funding was low with the exception of Lithuania.

\section{[TABLE 3]}

The association between ranks show that the GDP per capita is strongly related with the role of governments in domestic aid and personal care: on average, the higher the GDP per capita, the stronger the involvement in funding and regulation tends to be (see Table 3). It is most strongly associated with differences in funding of these services. With regard to home nursing such association is weak.

\section{Hypothesis 4}

. Expected that in countries with a relative large population of elderly people, government involvement would be larger. Although populations in all European countries are ageing, there are great differences in the current age-structures (see Table 2). In 2009, the highest old-age dependency ratios were found in Germany (31.4), Sweden, Greece and Italy; and the lowest ratio's in Ireland (16.8), Slovakia, Iceland and Cyprus. The association between the old-age dependency ratio and involvement in all three types of home care is weak.

\section{DISCUSSION}

Variation across Europe in the governmental involvement in financing, regulation and provision is evident. This study has explored several potential determinants of such cross-country differences that were put forward by previous studies [2], [7], [8], [9], [10], [12], [13] and [14], i.e. culture, economy or other institutions. It goes beyond these previous studies, by looking into associations between governmental involvement and the determinants using quantitative data from 30 countries and discerning between different types of home care.

This study indeed found evidence that in countries where the conditions for the involvement of informal care were stronger, the involvement of governments in home care is lower. Where many people strongly believe in informal care duties, 
Genet, N., Kroneman, M., Boerma, W.G.W. Explaining governmental involvement in home care across Europe: an international comparative study. Health Policy: 2013, 110(1), 84-93

governments tend to be less involved through funding and regulation in personal care and domestic aid. This corresponds with ideas of Pfau-Effinger and Geisler [8]. Although England is an exception, we could say that countries with mainly a dual earner - part-time carer model have a relatively high governmental involvement in home care funding and relatively low involvement in the provision of services. However, where the dual breadwinner/female carer model (Eastern European mainly) prevails no clear trend regarding governmental involvement in home care existed. This may be because in post-communist countries policy development advances differently, possibly due as many of them copied welfare systems from Germany, others from England.

It is difficult to explain, however, why we found a relationship for governmental involvement in funding and regulation and did not find such relationship with involvement in care provision, especially as a higher labour market participation of women is associated with more involvement in the provision of personal care and home nursing. Economic conditions might explain this gap between what is valued and what is done in practice. As the costs of home care rise fast across Europe, maybe decisions and governance mechanisms are chosen that go beyond what we would expect according to theories on care regimes.

Our hypothesis that a stronger role of government in society in general is associated with stronger involvement in home care was also partially supported. An association was mainly found with the higher tax burden. A negligible association was found between governmental involvement in home care and the dominant welfare value in a country (except for funding personal care and home nursing), as well as with the position of Social-democratic parties in cabinets over the past decade. A possible explanation is that in many countries, especially in Central and Eastern Europe, home care has only recently been developed and, hence, is related to political orientation only in recent years.

Governmental involvement in home care tends to be stronger in wealthier countries, except for involvement with home nursing and the involvement in provision, which both seemed largely unrelated to wealth. As other studies had shown [2] and [25], governments are more involved with health care services than with help oriented services. Possibly the higher priority of nursing services may weaken the association with wealth. Furthermore, when more people have paid jobs governments could be more likely to assure formal services that would otherwise have to be provided by the family. Finally, contrary to our expectations, involvement of governments in home care could not be explained by the share of elderly people in a country. Possibly this could be due to the fact that the more a society is aged and hence demand for home care grows, the less able governments are to expand their publicly funded home care sector - due to limited resources - and rather have to rely on privately financed home care.

In contrast to findings from the health care sector [13], this study did not find an association between governmental involvement and a historically stronger position of Social-democratic parties. As other studies suggested [8], [9] and [14], the governmental role in the home care sector is rather embedded in a national context of wealth and in cultural values. Perhaps, such relationship is less clear cut for Eastern European countries as they had to expand in a short period of time. 
Genet, N., Kroneman, M., Boerma, W.G.W. Explaining governmental involvement in home care across Europe: an international comparative study. Health Policy: 2013, 110(1), 84-93

Finally, this study showed that involvement in regulation and financing is on average stronger for home nursing than for the other types of home care. The lower financial and safety risks for domestic aid or personal care relative to home nursing, may explain why the former are more often left to families. This underlines the importance for international comparative research to compare specific services only and to use strict definitions.

In conclusion, economy, female labour market participation and indeed some cultural values are associated with the governments' role in home care. However, our study was not able to establish the causality of the relationship, since our study had a crosssectional design only and causality can be established in longitudinal research only.

\subsection{Strengths and limitations}

This paper is based on an extensive study that was able to show what data on home care is available across Europe and provided a set of indicators for home care developed by home care experts across Europe and a systematic literature review. This paper is a first attempt to explain differences in governmental involvement in home care through quantitative analysis. Quantitative analyses provide the opportunity to study associations and hence enable finding more than countryspecific historical explanations. It can provide leads for further research on the exact relationship of governmental involvement with the factors that were shown to be correlated such as the GDP per capita and family values.

In the absence of comparable data on straightforward indicators for governmental involvement, such as public expenditures on home care, this study had to rely on constructed indicators. Another limitation is that not all forms of governmental control were considered (such as information to people about service availability) and that the involvement of non-governmental organisations was not taken into account. For instance, the role of insurance companies, umbrella organisations for home care providers and charitable organisations have not been considered. Our focus on the national level has also been a limitation, as there are many local differences within countries, in some countries more than others. However, we have tried to minimise this limitation by assigning a medium score on governmental involvement if there usually was regulation, financing or delivery of home care on local level.

A usual limitation in international comparative analyses is the limited number of observations which are an obstacle to the use of multivariate analyses. Hence, where the ideographic historical accounts of home care may go too far in detailed explanations, quantitative research may oversee some important interactions.

\section{CONCLUSION}

Governments' role in controlling services differs strongly between countries, some with a stronger emphasis on regulating home care services and others on providing home care. Governments tend to put a stronger mark on funding and regulation of domestic aid and personal care, in countries where there are fewer people believing in informal care duties. Favourable conditions concerning female labour market participation are associated with stronger governmental involvement in home care provision. In wealthier countries and in countries with a higher tax burden there is a larger involvement of governments in funding and regulation of domestic aid and personal care. The share of elderly people in a country appeared to have little 
Genet, N., Kroneman, M., Boerma, W.G.W. Explaining governmental involvement in home care across Europe: an international comparative study. Health Policy: 2013, 110(1), 84-93

influence on home care regulation. The difference in governmental involvement in the different types of home care (home nursing, personal aid and provision) highlights the importance of making a distinction between these types of home care. Summarising, the study provides some evidence for the obstacles for transferring home care policies between countries, i.e. differences in economic development and differences in family values. However, longitudinal research is needed to establish whether the suggested causality is true. This study has furthermore shown that in most countries policies regarding home care do not necessarily seems to reflect the citizens' actual preferences.

\section{COMPETING INTERESTS}

The authors have stated that there are none.

\section{ACKNOWLEDGEMENTS}

This study was partially funded by the European Commission, DG Sanco. We would like to thank the EURHOMAP consortium. This consortium has helped with the setup of the EURHOMAP study and with gathering data. The consortium consisted of: Vjenka Garms-Homolová (Alice Salomon University of Applied Sciences, Berlin, Germany); Bonaventura Bolibar (IDIAP Jordi Gol Institute for Research in Primary Care, Barcelona, Spain); Michel Naiditch (IRDES, Institute for research and information in health economics, Paris, France); Laszlo Gulacsi and Katalin Ersek (Corvinus University, Budapest, Hungary); Giovanni Lamura (INRCA National Institute of Health and Science on Ageing, Ancona, Italy); Slawomir Chlabicz (Medical University of Bialystok, Bialystok, Poland); Ania Willman and Cecilia Fagerström (Blekinge Institute of Technology, Karlskrona, Sweden); Allen Hutchinson (University of Sheffield, Sheffield, United Kingdom). Furthermore, we would like to thank the country experts who have contributed in providing the data on which this study was based. Finally, we would like to thank Prof. Dr. A.L. Francke and Prof Dr. P. Groenewegen for their comments on the manuscript.

\section{Appendix A. Supplementary data}

\section{REFERENCES}

[1] Tarricone R, Tsouros A, editors. Home care in Europe. Copenhagen: World Health Organization; 2008.

[2] Burau V, Theobald H, Blank R. Governing home care: a cross national comparison. Cheltenham: Edward Elgar Publishing; 2007.

[3] Genet N, Boerma WGW, Kringos D, Bouman A, Fagerström C, Greco C, Melchiore M, Francke A, Devillé W. Home care in Europe: a systematic literature review. BMC Health Services Research 2011:16-8.

[4] Organization for Economic Cooperation and Development. Long-term care for older people. Paris: Organisation for Economic Co-operation and Development; 2005.

[5] Eurostat. Expenditure of selected health care functions by financing agents in health care 2003-2009. Retrieved September; 2012.

[6] Harrop M. Power and policy in liberal democracies. Cambridge: Cambridge University Press; 1992.

[7] Genet N, Kroneman M, Chiatti C, Gulácsi L, Boerma W. The policy per-spective In: Genet N, Boerma W, Kroneman M, Hutchinson A, Saltman R B., editors. Home Care across 
Genet, N., Kroneman, M., Boerma, W.G.W. Explaining governmental involvement in home care across Europe: an international comparative study. Health Policy: 2013, 110(1), 84-93

Europe: Current structure and future challenges. Copenhagen: WHO, Regional Office for Europe (on behalf of the European Observatory on Health Systems, Policies); 2012.

[8] Pfau-Effinger B, Geissler B, editors. Care and social integration in European societies. Bristol: Policy Press; 2005.

[9] Schmidt A, Cacace M, Götze R, Rothgang H. Explaining health sys-tem change: problem pressure and the emergence of "hybrid" health care systems, Journal of Health Politics. Policy and Law 2010;35(4):455-86.

[10] Anttonen A, Baldock J, Sipilä J, editors. The young, the old and the state. Cheltenham: Edward Elgar; 2003.

[11] Leira A, Saraceno C. Care: actors, relationships and contexts, The mul-tidimensional concept of care. In: Hobson B, Lewis J, Siim B, editors. Contested concepts in gender and social politics. London: Edward Elgar; 2003. p. 55-83.

[12] Esping-Andersen G. The three worlds of welfare capitalism. Prince-ton: Princeton University Press; 1990.

[13] Navarro V, Shi L. The political context of social inequalities and health. Social Science \& Medicine 2001;52(3):481-91.

[14] Vrooman J. Rules of relief; institutions of social security, and their impact. The Netherlands Institute for Social Research SCP: The Hague; 2009.

[15] Hemerijck A. The self-transformation of the European social model (s). In: Gallie G, Hemerijck D, Myles AJ, editors. Why we need a new welfare state. Esping-Andersen. Oxford: Oxford University Press; 2002. p. 173-244.

[16] Esping-Anderson G. The social foundations of postindustrial economies. Oxford: University Press; 1999.

[17] Bode I, Gardin L, Nyssens M. Quasi-marketisation in domiciliary care: varied patterns, similar problems? International Journal of Sociology and Social Policy 2011;31:3.

[18] TNS Opinion \& Social. Health and long-term care in the European Union: Special EUROBAROMETER Brussels: Directorate-General for Employment, Social Affairs and Equal Opportunities and coordinated by Directorate-General for Communication. 2007.

[19] Eurostat. Full-time equivalent employment rate 2007. Eurostat EU LFS. Retrieved in July 2011.

[20] Armingeon K, Careja R, Weisstanner D, Engler S, Potolidis P, Gerber M, Leimgruber P. Comparative Political Data Set III 1990-2009. Berne: Institute of Political Science; 2011. http://wwwipwunibech/content/team/klaus armingeon/comparative political data sets/ index enghtml

[21] Eurostat. Revenue of government through current taxes and social contributions on income, wealth, etc. 2007. Eurostat. Retrieved May 2011.

[22] Eurostat. GDP per capita - Annual Data 2009. Retrieved July 2011.

[23] Eurostat. Old-age dependency ratio 2010. Retrieved July 2011.

[24] Davis JA. Elementary survey analysis. Englewood Cliffs, New York: Prentice-Hall; 1971.

[25] Brandt M, Haberkern K, Szydlik M. Help and care between generations in Europe. European Sociological Review 2009;25(5): 585-601. 
Genet, N., Kroneman, M., Boerma, W.G.W. Explaining governmental involvement in home care across Europe: an international comparative study. Health Policy: 2013, 110(1), 84-93

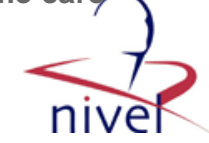

Table 1

Strength of governmental involvement in home care.

\begin{tabular}{|c|c|c|c|c|c|c|c|c|c|c|c|c|}
\hline \multirow[t]{2}{*}{ Country } & \multicolumn{3}{|l|}{ Funding } & \multicolumn{3}{|l|}{ Regulation } & \multicolumn{3}{|l|}{ Provision } & \multirow[t]{2}{*}{ Vision $^{\mathrm{b}}$} & \multirow[t]{2}{*}{ One ministry ${ }^{c}$} & \multirow[t]{2}{*}{ Type of scheme ${ }^{d}$} \\
\hline & Domestic aid & Personal care & Nursing & Domestic aid & Personal care & Nursing & Domestic aid & Personal care & Nursing & & & \\
\hline Austria & 1.0 & 1.0 & 0.8 & 0.7 & 0.7 & 0.6 & 0.0 & 0.0 & 0.0 & $\mathrm{x}$ & $\mathrm{x}$ & soc-hlth \\
\hline Belgium & 0.9 & 1.0 & 1.0 & 0.6 & 0.8 & 0.8 & 0.0 & 0.0 & 0.0 & $\mathrm{x}$ & $\mathrm{x}$ & soc-hlth \\
\hline Bulgaria & 0.3 & 0.7 & 0.2 & 0.1 & 0.1 & 0.0 & 0.3 & 0.7 & 0.0 & 0 & $\mathrm{x}$ & several \\
\hline Switzerland & 1.0 & 1.0 & 1.0 & 0.5 & 0.7 & 0.7 & 0.5 & 0.5 & 0.5 & $\mathrm{x}$ & . & soc-hlth \\
\hline Cyprus & 0.5 & 0.7 & 1.0 & 0.4 & 0.4 & 0.8 & 0.5 & 0.7 & 1.0 & $\mathrm{x}$ & $\mathrm{x}$ & soc-hlth \\
\hline Gech Rep. & 0.5 & 1.0 & 1.0 & 0.5 & 0.8 & . & 0.4 & 0.8 & . & 0 & $\mathrm{x}$ & soc-hlth \\
\hline Germany & 1.0 & 1.0 & 1.0 & 1.0 & 1.0 & 1.0 & 0.0 & 0.0 & 0.0 & $\mathrm{x}$ & & soc-hlth \\
\hline Denmark & 0.9 & 1.0 & 1.0 & 0.4 & 0.5 & 0.5 & 0.9 & 1.0 & 1.0 & $\mathrm{x}$ & $\mathrm{X}^{1}$ & soc-hlth \& duration \\
\hline Spain & 0.5 & 0.7 & 1.0 & 0.1 & 0.1 & 0.5 & 0.5 & 0.7 & 0.5 & $\mathrm{x}$ & & soc-hlth \\
\hline Estonia & 0.7 & 0.7 & 1.0 & . & . & 0.3 & 0.7 & 0.3 & 0.0 & 0 & & soc-hlth \\
\hline Finland & 1.0 & 1.0 & 1.0 & 0.3 & 0.3 & 0.3 & 1.0 & 1.0 & 1.0 & $\mathrm{x}$ & & age \\
\hline France & 1.0 & 1.0 & 1.0 & 0.8 & 0.8 & 0.8 & 0.5 & 0.5 & 0.5 & $\mathrm{x}$ & & soc-hlth \& age \\
\hline Greece & 0.7 & 0.7 & 0.7 & 0.3 & 0.3 & 0.3 & 0.7 & 0.7 & 0.3 & $\mathrm{x}$ & . & several \\
\hline Croatia & 0.3 & 0.8 & 0.7 & . & 0.3 & 0.3 & 0.2 & 0.4 & 0.3 & $\mathrm{x}$ & & . \\
\hline Hungary & 0.5 & 0.4 & 0.8 & . & 0.3 & 0.7 & 0.5 & 0.2 & 0.4 & 0 & $\mathrm{x}$ & soc-hlth \\
\hline Ireland & 0.5 & 0.7 & 0.7 & 0.2 & 0.2 & 0.2 & 0.5 & 0.7 & 0.7 & $\mathrm{x}$ & $\mathrm{x}$ & soc-hlth \\
\hline Iceland & 0.5 & 1.0 & 1.0 & 0.0 & 0.3 & 0.3 & 0.3 & 1.0 & 1.0 & & & soc-hlth \\
\hline Italy & 0.7 & 0.7 & 1.0 & 0.2 & 0.2 & 0.5 & 0.5 & 0.5 & 1.0 & $\mathrm{x}$ & $\mathrm{x}$ & soc-hlth \\
\hline Lithuania & 0.9 & . & 1.0 & 0.3 & . & 1.0 & 0.9 & . & 0.5 & $\mathrm{x}$ & $\mathrm{x}$ & duration \\
\hline Luxembourg & 1.0 & 1.0 & 0.8 & 0.7 & 0.7 & 0.6 & 0.0 & 0.0 & 0.0 & $\mathrm{x}$ & $\mathrm{x}$ & duration \& soc-hlth \\
\hline Latvia & 0.7 & 0.7 & 1.0 & 0.2 & 0.2 & 0.8 & 0.5 & 0.5 & 0.5 & 0 & $\mathrm{x}$ & soc-hlth \\
\hline Malta & 0.5 & 0.7 & 1.0 & 0.5 & 0.6 & 0.8 & 0.5 & 0.3 & 0.0 & $\mathrm{x}$ & & soc-hlth \\
\hline Netherlands & 1.0 & 1.0 & 1.0 & 0.3 & 0.8 & 0.8 & 0.0 & 0.0 & 0.0 & $\mathrm{x}$ & & soc-hlth \\
\hline Norway & 0.9 & 1.0 & 1.0 & 0.6 & 0.8 & 0.8 & 0.9 & 1.0 & 1.0 & $\mathrm{x}$ & & soc-hlth \\
\hline Poland & 0.5 & 0.7 & 1.0 & 0.1 & 0.1 & 0.7 & 0.5 & 0.7 & 0.5 & 0 & $\mathrm{x}$ & soc-hlth \\
\hline Romania & 0.4 & 0.5 & 0.3 & . & . & . & 0.3 & 0.4 & 0.3 & & $\mathrm{x}$ & soc-hlth \& age \\
\hline Slovak Rep. & 0.9 & 1.0 & 0.8 & 0.4 & 0.5 & 0.6 & 0.9 & 1.0 & 0.0 & $\mathrm{x}$ & $\mathrm{x}$ & soc-hlth \\
\hline Slovenia & 0.5 & 0.7 & 1.0 & 0.2 & 0.3 & 0.7 & 0.4 & 0.5 & 0.8 & 0 & $\mathrm{x}$ & several \\
\hline Sweden & 0.9 & 1.0 & 1.0 & 0.6 & 0.7 & 0.5 & 0.9 & 1.0 & 1.0 & $\mathrm{x}$ & & age \\
\hline UK (England)) & 0.5 & 0.8 & 1.0 & 0.3 & 0.4 & 0.7 & 0.3 & 0.4 & 0.5 & $\mathrm{x}$ & & soc-hlth \\
\hline
\end{tabular}

Source: EURHOMAP-project data; situation in 2009.

${ }^{a}$ Explanation construction variables see supplementary data 1; $0=$ no involvement, $1=$ maximum involvement. $=$ no information available.

b ' $\mathrm{X}$ ' refers to there being a national vision on home care that is written down in a formal document both for all types of home care; ' 0 ' refers to there being such vision only for one or two of the types of home care, and if there is no such vision at all there is an empty cell.

c Answer to question 'is the governance on home care divided over more than one ministry?' $\mathrm{X}$ indicates that there is

d 'Duration' refers to there being different home care schemes for long-term care than for short-term care; 'age' refers to different home care schemes for elderly care and adult care; "soc-hlth" refers to there being different home care schemes for social home care services and home health care; 'common scheme' means that there is in general only one home care scheme; 'several' refers to there being many separate home care schemes. 
Genet, N., Kroneman, M., Boerma, W.G.W. Explaining governmental involvement in home care across Europe: an international comparative study. Health Policy: 2013, 110(1), 84-93

Table 2

Differences in conditions for the role government, family, wealth and old age dependency ratio.

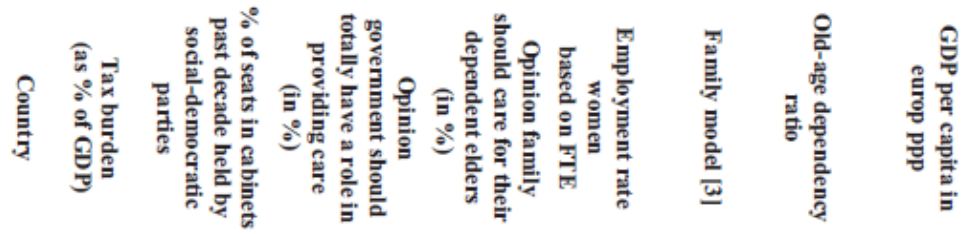

\begin{tabular}{|c|c|c|c|c|c|c|c|c|}
\hline AUT & 289 & 27.6 & 54 & 28 & 54.7 & $\overline{F p}$ & 26.1 & 32.800 \\
\hline BEL & 32.7 & 51.6 & 67 & 25 & 45.3 & $\mathrm{Fp}$ & 26.0 & 31.400 \\
\hline BGR & 18.6 & 20.6 & 60 & 58 & 61.1 & Df & 25.4 & 4.600 \\
\hline CHE & 21.1 & 28.6 & . & . & 51.7 & . & 24.7 & 45.500 \\
\hline CYP & 15.2 & 16.3 & 92 & 29 & 59.7 & Df & 18.6 & 21.200 \\
\hline CZE & 24 & 39.9 & 59 & 57 & 56.8 & Df & 21.6 & 13.100 \\
\hline DEU & 29.1 & 53.9 & 65 & 35 & 50.3 & $\mathrm{Fp}$ & 31.4 & 29.300 \\
\hline DNK & 32.8 & 41,2 & 85 & 18 & 59.9 & $\mathrm{Db}$ & 24.9 & 40.300 \\
\hline ENG & 22.4 & 72.9 & 68 & 30 & 51.7 & Fp & 24.9 & 25.300 \\
\hline ESP & 22.6 & 50.3 & 73 & 40 & 48.1 & $\mathrm{Hw}$ & 24.7 & 22.900 \\
\hline EST & 23.2 & 28.8 & 74 & 49 & 63.5 & Df & 25.2 & 10.300 \\
\hline FIN & 32 & 38.6 & 70 & 20 & 60.1 & $\mathrm{Db}$ & 25.6 & 32.500 \\
\hline FRA & 28.4 & 32.6 & 70 & 17 & 52.1 & $\mathrm{Fp}$ & 25.6 & 29.300 \\
\hline GRC & 17.8 & 65.1 & 54 & 44 & 47.9 & $\mathrm{Hw}$ & 28.4 & 20.800 \\
\hline HRV & & . & 74 & 50 & 49.1 & $\mathrm{Hw}$ & 25.6 & 10.300 \\
\hline HUN & 23.4 & 54.7 & 39 & 48 & 50.1 & $\mathrm{Hw}$ & 24.2 & 9.300 \\
\hline IRL & 20.2 & 13.5 & 63 & 32 & 45.8 & $\mathrm{Fp}$ & 16.8 & 35.700 \\
\hline ISL & 15.4 & 12 & . & . & 66.2 & Df & 17.9 & 27.100 \\
\hline ITA & 28.9 & 29 & 51 & 48 & 39.5 & $\mathrm{Hw}$ & 30.8 & 25.200 \\
\hline LTU & 15.6 & 52.3 & 62 & 46 & 59.6 & Df & 23.3 & 7900 \\
\hline LUX & 26.3 & 30.7 & 72 & 13 & 45.1 & $\mathrm{Fp}$ & 20.4 & 76.600 \\
\hline LVA & 19.1 & 17.6 & 65 & 47 & 62.5 & Df & 25.2 & 8.200 \\
\hline MLT & 15.5 & 11.6 & 68 & 23 & 31.7 & $\mathrm{Hw}$ & 21.3 & 14.200 \\
\hline NLD & 29.4 & 28.1 & 70 & 13 & 44.2 & $\mathrm{Fp}$ & 22.8 & 34.600 \\
\hline NOR & 259 & 55.7 & . & . & 57.3 & . & 22.5 & 55.300 \\
\hline POL & 23 & 37.1 & 51 & 61 & 50.6 & $\mathrm{Hw}$ & 19.0 & 8.100 \\
\hline ROM & 18.4 & 56.9 & 58 & 46 & 51,1 & $\mathrm{Hw}$ & 21.4 & 5.500 \\
\hline SVK & 259 & 25.4 & 53 & 48 & 54.5 & $\overline{\mathrm{Df}}$ & 16.9 & 11.600 \\
\hline SVN & 23.9 & 48.2 & 61 & 44 & 63.7 & Df & 23.8 & 17.300 \\
\hline SWE & 32.4 & 75 & 80 & 7 & 59.8 & $\mathrm{Db}$ & 27.7 & 31.300 \\
\hline
\end{tabular}

Note: the family model abbreviations used were: fp-female part-time carer model of the male breadwinner family; df-dual breadwinner/female carer model; hw - housewife model of the male breadwinner family; db - dual breadwinner model, based on Bureau et al. [3] decided to look at opinion on family care in combination with female labour market participation. When the country scored $25 \%$ and $55 \%$ respectively on these two indicators we assumed the dual breadwinner/female carer model was prevalent. Finally, we assigned countries where more than $30 \%$ of the working women worked part-time to the group of the female part-time carer. In case of opinion indicator above $25 \%$ is high and in case of the labour market participation of women this is said to be high if over $55 \%$. 
Genet, N., Kroneman, M., Boerma, W.G.W. Explaining governmental involvement in home care across Europe: an international comparative study. Health Policy: 2013, 110(1), 84-93

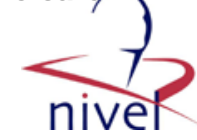

Table 3

Testing the hypotheses.

\begin{tabular}{|c|c|c|c|}
\hline Governmental irvolvement in & Explanatory variable & Association Spearman's rho & N \\
\hline \multicolumn{4}{|l|}{ Domestic aid } \\
\hline \multirow[t]{7}{*}{ Funding } & Farnily value & -0.60 & 27 \\
\hline & Labour market participation women & -0.05 & 30 \\
\hline & Welfare value & 0.16 & 27 \\
\hline & Tax burden & 0.63 & 29 \\
\hline & Share seats cabinet held by social-democrats & 0.03 & 29 \\
\hline & GDP per capita & 0.64 & 30 \\
\hline & Old-age dependency ratio & 0.29 & 30 \\
\hline \multirow{7}{*}{ Regulation } & Family value & -0.59 & 23 \\
\hline & labour market participation women & -0.21 & 26 \\
\hline & Welfare value & 0.29 & 23 \\
\hline & Tax burden & 0.52 & 26 \\
\hline & Share seats cabinet held by social-democrats & 0.24 & 26 \\
\hline & GDP per capita in Euro & 0.50 & 26 \\
\hline & Old-age dependency ratio & 0.28 & 26 \\
\hline \multirow[t]{7}{*}{ Provision } & Family value & 0.03 & 27 \\
\hline & labour market participation women & 0.29 & 30 \\
\hline & Welfare value & 0.09 & 27 \\
\hline & Tax burden & -0.06 & 29 \\
\hline & Share seats cabinet held by social dernocrats & 0.14 & 29 \\
\hline & GDP per capita in Euro & -0.08 & 30 \\
\hline & Old age dependency ratio & -0.13 & 30 \\
\hline \multicolumn{4}{|l|}{ Personal care } \\
\hline \multirow[t]{7}{*}{ Funding } & Family value & -0.53 & 26 \\
\hline & labour market participation women & 0.12 & 29 \\
\hline & Welfare value & 0.33 & 26 \\
\hline & Tax burden & 0.61 & 28 \\
\hline & Share seats cabinet held by social-democrats & 0.02 & 28 \\
\hline & GDP per capita & 0.69 & 29 \\
\hline & Old-age dependency ratio & 0.14 & 29 \\
\hline \multirow[t]{7}{*}{ Regulation } & Family value & -0.60 & 24 \\
\hline & labour market participation women & -0.08 & 27 \\
\hline & Welfare value & 0.26 & 24 \\
\hline & Tax burden & 0.50 & 26 \\
\hline & Participation of social-democrats in cabinets & 0.20 & 26 \\
\hline & GDP per capita & 0.56 & 27 \\
\hline & Old-age dependency ratio & 0.11 & 27 \\
\hline \multirow[t]{7}{*}{ Provision } & Family value & 0.12 & 26 \\
\hline & labour market participation women & 0.49 & 29 \\
\hline & Welfare value & 0.08 & 26 \\
\hline & Tax burden & -0.09 & 28 \\
\hline & Share seats cabinet held by social democrats & 0.00 & 28 \\
\hline & GDP per capita & 0.03 & 29 \\
\hline & Old age dependency ratio & -0.23 & 29 \\
\hline \multicolumn{4}{|l|}{ Home nursing } \\
\hline \multirow[t]{6}{*}{ Funding } & Family value & -0.27 & 27 \\
\hline & Labour market participation women & 0.22 & 30 \\
\hline & Welfare value & 0.37 & 27 \\
\hline & Tax burden & 0.22 & 29 \\
\hline & Share seats cabinet held by social-dernocrats & 0.05 & 29 \\
\hline & $\begin{array}{l}\text { GDP per capita } \\
\text { Old-age dependency ratio }\end{array}$ & $\begin{array}{l}0.23 \\
0.07\end{array}$ & $\begin{array}{l}30 \\
30\end{array}$ \\
\hline \multirow[t]{7}{*}{ Rezulation } & Farnily value & -0.24 & 25 \\
\hline & labour market participation women & -0.13 & 28 \\
\hline & Welfare value & -0.04 & 25 \\
\hline & Tax burden & 0.04 & 27 \\
\hline & Share seats cabinet held by social-dernocrats & 0.14 & 27 \\
\hline & GDP per capita & 0.01 & 28 \\
\hline & Old-age dependency ratio & -0.11 & 28 \\
\hline \multirow[t]{4}{*}{ Provision } & Family value & -0.12 & 26 \\
\hline & labour market participation women & 0.38 & 29 \\
\hline & Welfare value & 0.20 & 26 \\
\hline & Tax burden & -0.01 & 28 \\
\hline
\end{tabular}

Table 3 (Continued)

\begin{tabular}{llcl}
\hline Governmental involvement in & Explanatory variable & Association Spearmar's rho & $\mathrm{N}$ \\
\hline & Participation of social-democrats in cabinets & 0.11 & 28 \\
& GDP per capita & 0.22 & 29 \\
& Old age dependency ratio & -0.09 & 29
\end{tabular}


Genet, N., Kroneman, M., Boerma, W.G.W. Explaining governmental involvement in home care across Europe: an international comparative study. Health Policy: 2013, 110(1), 84-93

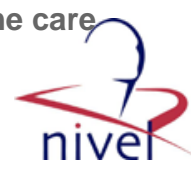

Appendix A.

Supplementary data 2 Descriptive statistics

N Mean St. dev

Variables (values)

Outcome variables

Funding

Number of funded services

\begin{tabular}{rrrr}
$\begin{array}{r}\text { domestic aid } \\
\text { (ranging from } 0(0) \text { to } 1(4) \text { ) }\end{array}$ & 30 & 0.775 & 0.249 \\
$\begin{array}{r}\text { personal care } \\
\text { (ranging from } 0(0) \text { to } 1(5) \text { ) }\end{array}$ & 30 & 0.927 & 0.170 \\
nursing & 30 & 0.878 & 0.255 \\
(ranging from $0(0)$ to $1(3)$ ) & & & \\
\hline
\end{tabular}

Population covered by funded services

$(1=$ all population in need of care; $0.333=$ only part of population in need of care)

\begin{tabular}{|lccccc|}
\hline & domestic aid & 30 & 0.644 & 0.338 \\
\hline & personal care & 29 & 0.701 & 0.338 \\
\hline home nursing & 30 & 0.911 & 0.231
\end{tabular}

\section{Total funding}

\begin{tabular}{|rrrrr}
\hline & domestic $^{\text {aid }^{\mathbf{a}}}$ & 30 & 0.710 & 0.227 \\
\hline & personal care $^{\mathbf{a}}$ & 29 & 0.819 & 0.193 \\
\hline nursing $^{\mathbf{a}}$ & 30 & 0.894 & 0.208
\end{tabular}

\section{Regulation}

Strength regulation on quality of care process and output

(1=yes; $0.5=$ by local government ; $0=$ no)

\begin{tabular}{|lcrrr|}
\hline & domestic aid & 29 & 0.397 & 0.363 \\
\hline & personal care & 29 & 0.448 & 0.408 \\
\hline & home nursing & 29 & 0.517 & 0.366
\end{tabular}

\section{Setting service prices}

(1=national; $0.5=$ national $\max$ and/or minimum; $0=$ no $)$

$\begin{array}{llll}\text { domestic aid } & 27 & 0.333 & 0.439\end{array}$


Genet, N., Kroneman, M., Boerma, W.G.W. Explaining governmental involvement in home care across Europe: an international comparative study. Health Policy: 2013, 110(1), 84-93

niver

N Mean St. dev

Variables (values)

\begin{tabular}{|llll} 
personal care & 29 & 0.500 & 0.463 \\
& & & \\
\hline home nursing & 29 & 0.621 & 0.456
\end{tabular}

\section{Setting eligibility criteria}

(1= mainly set by national government; $0.5=$ mainly by local government ;

$0=$ no)

\begin{tabular}{|lcrrr|}
\hline domestic aid & 30 & 0.717 & 0.284 \\
\hline personal care & 30 & 0.700 & 0.311 \\
\hline home nursing & 30 & 0.750 & 0.366
\end{tabular}

Total regulation

\begin{tabular}{|cccc|}
\hline domestic aid & 26 & 0.390 & 0.244 \\
\hline personal care & 27 & 0.487 & 0.264 \\
\hline home nursing & 28 & 0.598 & 0.246 \\
\hline
\end{tabular}

\section{Provision}

Main provider services

(1=mainly public $; 0.5=$ mix; $0=$ mainly private)

\begin{tabular}{|lcccc}
\hline domestic aid & 30 & 0.700 & 0.447 \\
\hline personal care & 30 & 0.700 & 0.447 \\
\hline home nursing & 29 & 0.517 & 0.509
\end{tabular}

Main needs assessor for receiving services

(1=mainly public $; 0.5=$ mix; $0=$ mainly private)

\begin{tabular}{|cccc|}
\hline domestic aid & 30 & 0.717 & 0.429 \\
\hline personal care & 30 & 0.650 & 0.458 \\
\hline home nursing & 30 & 0.500 & 0.491 \\
\hline
\end{tabular}

Total provision

\begin{tabular}{|rrrrr|}
\hline & domestic aid & 30 & 0.468 & 0.298 \\
\hline & personal care & 29 & 0.526 & 0.336 \\
\hline nursing & 29 & 0.457 & 0.386
\end{tabular}

\section{Explanatory variables}

1. GDP per capita in Euro at current prices 
Genet, N., Kroneman, M., Boerma, W.G.W. Explaining governmental involvement in home care across Europe: an international comparative study. Health Policy: 2013, 110(1), 84-93

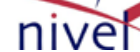

\begin{tabular}{|c|c|c|c|}
\hline Variables (values) & $\mathbf{N}$ & Mean & St. dev \\
\hline 2. Old-age dependency ratio & 30 & 23.757 & 3.650 \\
\hline $\begin{array}{l}\text { 3. Share of people thinking that the state should provide care for } \\
\text { elderly dependent people (welfare value) }\end{array}$ & 27 & 65.111 & 11.298 \\
\hline $\begin{array}{l}\text { 4. Income of government through current taxes and social } \\
\text { contributions }\end{array}$ & 29 & 23.866 & 5.570 \\
\hline $\begin{array}{l}\text { 5. Share of cabinet posts held by social-democratic parties between } \\
\text { 1992-2008 }\end{array}$ & 29 & 38.476 & 17.969 \\
\hline Role of government in society in general & 26 & 1.00 & 0.168 \\
\hline $\begin{array}{l}\text { 6. Share of people thinking that people should care for their dependent } \\
\text { elderly parents even if it means that they have to give up to some extent } \\
\text { their work (family value) }\end{array}$ & 27 & 36.148 & 15.326 \\
\hline 7. Share of women between the age of 18-65 being employed & 30 & 53.120 & 7.897 \\
\hline Informal care & 27 & 1.010 & 0.196 \\
\hline
\end{tabular}

${ }^{\text {a }}$ see the methodology section for the construction of these variables 
Genet, N., Kroneman, M., Boerma, W.G.W. Explaining governmental involvement in home care across Europe: an international comparative study. Health Policy: 2013, 110(1), 84-93

\section{Supplementary data 1. Construction of variables}

\section{Funding}

In the absence of reliable and comparable data on public expenditures the governmental involvement in funding was measured as:

- the proportion of services from a list which are publicly funded (through taxes or social insurance: 1 when all publicly funded; 0 when none are),

- recipients' income being a criterion for eligibility to these services (1 if there is no such criteria; 0.33 when publicly funded services are only available for people with an income below a certain threshold). (The lower score was set below 0.5 as the eligible part of the population - the relatively 'poor' - is a minority).

Three groups of services were considered: (1) Domestic aid, including housekeeping, shopping, administration and meals-on-wheels. (2) Help with personal care, including washing, dressing, eating, putting on aids and, transfers in the home; (3) Home nursing, including changing stoma's, skin care and help with using medicine. For each group of services the 'governmental involvement via funding' was measured by a combined score, being the average score of both indicators.

\section{Regulation}

Governmental involvement in regulation on home care was measured through the availability of:

- $\quad$ explicit eligibility criteria $(0=$ no; $0.5=$ mainly set by local government; 1=mainly set by national government); 
Genet, N., Kroneman, M., Boerma, W.G.W. Explaining governmental involvement in home care across Europe: an international comparative study. Health Policy: 2013, 110(1), 84-93

- national price regulation $(0=$ no; $0.5=$ national $\max$ and/or minimum; $1=$ national);

- quality norms and regulation on national level $(0=$ no; $0.5=$ by local government; 1=yes).

The score for 'regulation' was the average of these three indicators. This was then weighed for coverage of funding, by multiplying it with the score on 'funding' as this regulation applies usually only to these services.

Provision of home care

Provision of home care was measured in a similar way:

- provision predominant public or private (where 1= mainly publicly provided; $0=$ mainly privately provided; $0.5=$ mixed public and private);

- needs assessment predominant performed by public or private organisations (where $1=$ mainly public; $0=$ mainly private ; $0.5=$ mixed public and private).

The score for 'provision' was the average of these two indicators. This was then weighed for coverage of funding, by multiplying it with the score on 'funding' . Independent variables

(1) the dominant family value measured by the agreement to the statement: "Care should be provided by close relatives of the dependent person, even if that means that they have to sacrifice their career to some extent” (Special Eurobarometer 2007; TNS Opinion \& Social); and (2) the share of the female population between age 18 
Genet, N., Kroneman, M., Boerma, W.G.W. Explaining governmental involvement in home care across Europe: an international comparative study. Health Policy: 2013, 110(1), 84-93

and 65 that was in paid employment in 2007 (Eurostat, July 2011). The indicator for the role of informal care was composed by the average of the relative country scores on each indicator (relative means that these are compared to the average score across countries). This was done only after making the indicators of informal care unidirectional, i.e. reversing the score on labour market participation of women. As indicators for the role of the government in society this study looks into (1) the average percentage of cabinet posts held by social-democratic parties between 19922008 (Armingeon et al., 2011); (2) the revenue of government through current taxes and social contributions on income, wealth, etc.: as a share of the GDP in 2007 (Eurostat, May 2011) and (3) the dominant welfare value measured through the share of respondents in the survey thinking that the state should provide care for elderly dependent people (Special Eurobarometer 2007). The indicator for government involvement in society was composed in the same way as the indicator for the role of informal care. Wealth was measured through the GDP per capita in Euro against current prices in 2009 and the old age dependency ratio was derived from 2010 (Eurostat, July 2011). 